\title{
Utilitarian Carcinogenesis: The Hazardous Occupations
}

\author{
Anubha Bajaji* \\ Deputy General Manager, LTFoods Ltd., LT Group Company (Daawat Basmati Rice), India
}

Submission: January 07, 2018; Published: March 22, 2018

"Corresponding author: Anubha Bajaj, Deputy General Manager, LT Foods Ltd, LT Group Company (Daawat Basmati Rice), India, Email: anubha.bajaj@gmail.com

\section{Opinion}

A carcinogen is an entity that bolsters carcinogenesis (abnormal growth and proliferation of abnormal cells or abnormal amount of cells which exceeds and is uncoordinated with that of the normal tissue and persists in the same excessive manner after the cessation of stimuli which evoked the conversion, due to a benign or malignant process). Co carcinogens are chemicals that do not commence carcinogenesis but assist the functioning of alternative carcinogens (work symbiotically with a carcinogen and enhance it's effect by direct concurrence on the local tissue). A procarcinogen is a harbinger to a carcinogen (a chemical substance that becomes carcinogenic after alteration due to a metabolic process) e.g.nitrites in dietary consumption. They are not carcinogenic themselves but conversion to nitrosamines in the body can be mutagenic.

\section{Contrivance to Carcinogenesis}

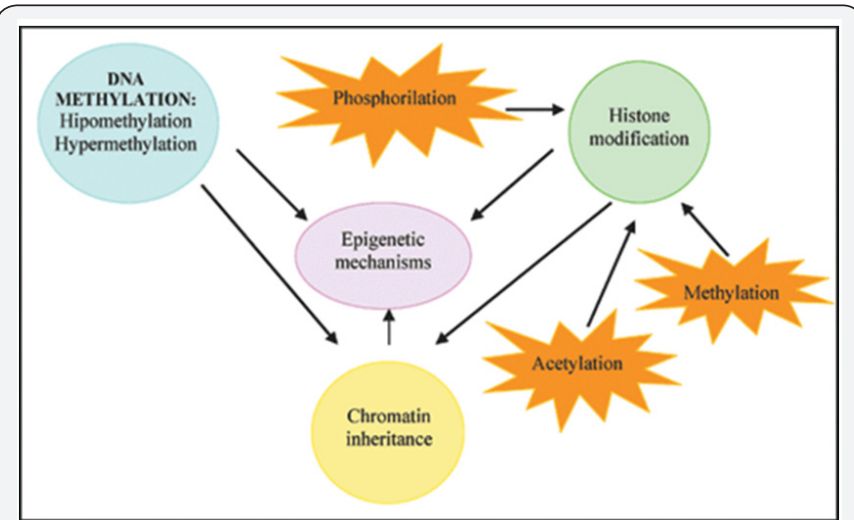

Figure 1: Epigenetic mechanisms involved in chemical carcinogenesis.

Carcinogens are catergorized as Genotoxic and NonGenotoxic. Genotoxins commence with irreversible genetic breakage or mutations by adhering to the Deoxyribonucleic acid (DNA) .Genotoxins enlist chemical agents like N-nitroso-Nmethylurea(NMU) or non chemical agents like ultraviolet light and ionizing radiation. Specific viruses can also accomplish carcinogenesis by collaborating with the DNA, Non genotoxins do not categorically disturb the DNA but operate differently to encourage growth. These include hormones and some organic compounds (Figure 1).

The International Agency for Research on Cancer (IARC) is an intergovernmental agency (in Lyon, France) organized in 1965 and a constituent of World Health Organization of the United Nations. It, therefore, communicates treatise on the estimation of carcinogenic contingencies to humans, with authoritative cataloguing of credible carcinogens:

a) Group 1: the agent (mixture) is definitely carcinogenic to humans. The exposure circumstance entails susceptibilities that are carcinogenic to humans.

b) Group 2 A: The agent (mixture) is probably carcinogenic to humans. The exposure .circumstance requires susceptibilities that are probably carcinogenic to humans.

c) Group2 B: the agent (mixture) is possibly carcinogenic to humans. The exposure circumstance results in vulnerabilities that are possibly carcinogenic to humans.

d) Group 3: the agent (mixture) is not analyzed as carcinogenic to humans. The exposure circumstance evokes declarations that are not allocated as carcinogenic to humans.

e) Group 4: the agent (mixture) is probably not carcinogenic to humans. The exposure circumstance involves presentation that are probably not carcinogenic to humans (Table 1). 


\section{Advanced Research in Gastroenterology \& Hepatology}

Table 1

\begin{tabular}{|c|c|c|}
\hline Carcinogens & Neoplastic Affiliations & Source \\
\hline Arsenic Compounds & Lung, Skin, Mesenchyme & Smelters, Alloys, Fungicides, Electrical Devices \\
\hline Asbestos & $\begin{array}{l}\text { Lung, G I Tract, Mesotheliomas (Pleural/ } \\
\text { Peritoneal) }\end{array}$ & $\begin{array}{l}\text { Construction( roof/floor tiles), friction linings, } \\
\text { fire resistant clothing }\end{array}$ \\
\hline Benzene & Leukaemia/Lymphoma( Hodgkin) & $\begin{array}{l}\text { Print, Lithography Paint Rubber Industry, Dry } \\
\text { Cleans, Adhesives, Coatings }\end{array}$ \\
\hline Beryllium Compounds & Lung & Alloys, aerospace, nuclear reactors \\
\hline \multirow[t]{2}{*}{ Cadmium Compounds } & Prostate & Batteries, Solders, Metal Paint /Coats \\
\hline & Lung & Paints, Pigments Preservatives \\
\hline Engine Exhaust Fumes/Gas & Lung, Bladder & Engines and Exhaust \\
\hline Ethylene Oxide & Leukaemia & $\begin{array}{c}\text { Ripeners for fruits/nuts, rocket propellant, } \\
\text { Fumigants, Sterlizers }\end{array}$ \\
\hline Nickel Compounds & Nose, Lung & $\begin{array}{l}\text { Nickel plating, Ferrous alloys, Batteries, } \\
\text { Ceramics, Welding products }\end{array}$ \\
\hline Radon and decays & Lung & Uranium decay, poor ventilation. \\
\hline Vinyl Chloride & Liver, Haemangiosarcoma & $\begin{array}{c}\text { Refrigerants, Plastic Adhesives, Polyvinyl } \\
\text { Chloride }\end{array}$ \\
\hline $\begin{array}{l}\text { Radium -226, Radium -224, Plutonium-239, } \\
\text { alpha particle emitters }\end{array}$ & Bone, Liver & Nuclear fuel, Radium dial processing \\
\hline Passive Smoking (Second Hand Smoke) & Lung & \\
\hline
\end{tabular}

Environmental carcinogens: Physicochemical agents such as beta napthylamine, aromatic amines, azo compounds, radiation, inorganic and organic compounds, polymers from derivatives of packing, handling, shipping, processing, using and consuming are insinuated. Appended environmental (occupational) carcinogens are dietary agents, additives, contaminants, processing and packaging products, natural constituents, consumer goods, cosmetics, over the counter drugs, rubber, household, sanitary products, contraceptives, medicines- synthetic and natural chemicals, metal and synthetic implants Habits, hobbies and customs such as snuffing, chewing tobacco, sun bathing, non circumcision, water, air, soil pollutants, selenium aliphatic / aromatic hydrocarbons are implicated along with co-incident carcinogens i.e gasoline, lead, alkylating agents, alcohol, antineoplastic agents, ultravoilet radiation from UV lamps, other ionizing radiation ( $\mathrm{X}$-rays/Gamma rays) [1].

\section{Prevention of Occupational Carcinogenesis}

Outrightand cyclical gradingfor chemicals isdesiredalongwith medical surveillance for patients with perpetual exposure with eradication of carcinogenic agent e.g .betanapthylamine, 4 diphenylamine. To avert or restrain carcinogenic proximity, capitalization of a clicker or an exclusive system is advocated. However, that one may not invariably be feasible. e.g for those associated with.the activities of packing, shipping etc. Permutation of carcinogen to a non carcinogenic admixture e.g.alphanapthylamine (contains 2 to $5 \%$ of betanapthylamine), diphenylamine from carcinogenic 4 aminodiphenyl, carcinogenic dusts and vapours can be condensed by wet treatment and water insoluble amalgamation. Hood and exhaust purification and installation for elimination of carcinogenic dust, fumes, mists, sprays and vapours are counselled along with depositories of mutagenic crude material and debris in ancient outbuildings or mine conduits, to conserve and protect the community from wind or water substrate percolation. For station of generation of ionizing radiation, a proviso of shielding devices for operators and adjacent room personnel is justified.

A. Industrial Hygiene:Acceptably sanitized domestic plants with non-existent aromatic amines and radioactive materials is necessitated. All machinery and mechanical appliances engaged in curtailing or dismissing mutagenic exposure e.g. hoods. exhausts, filters, scrubbers, radiation shields etc should be intermittently inspected for suitable functioning. Appropriate conservative and preventative measures to bona fide engineers and accident control personnel are to be administered with commensurate casualty containment. .Isochronous examination of scrap clearance can be instituted to figure concentration and physicochemical status of carcinogens. Habitual oversight, conformity and defensive criterion, safety regulations and mechanical upkeep should be established besides trained technicians. Operatives submitted to carcinogenic exposition should be administered with the correct insulators, goggles, respirators, gloves, boots, barrier creams etc. Adulterated apparel should be cleaned in the workplace with competence and immunity. Ablution before departure, refreshments in a discrete area after careful cleansing of extremities should be decreed. Contaminated, disregardful artisans must not be engaged. Entire calamities, chinks, breaches in pipeline should be addressed, chronicled and duly restored. Legitimate labelling and subsistence of cautionary signals of cervices, cracks, spillage are to be affixed. All bunkers for shipping must necessarily be well characterized and comprise of rummage disposal. 
B. Medical Benchmarks: Perennial medical assessment of operators and technical cadre: pulmonary x-rays (for soot, asbestos, chromium, beryllium, arsenic, nickel, mustard gas, isopropyl oil hazard) bones, nasal sinuses, cystoscopy (for aromatic amines, dyes, rubber, antioxidants liability) alongwith examination subsisting of laryngoscopy rhinoscopy, blood, urine, fluid discharge. Bone marrow evaluation is needed (for benzol susceptibility). Consequential to a drawn out dormancy of occupational malignancies medical surveillance should persist for 20 to 30 years following cessation of hazardous endangerment, or for as short as 6 months duration.

\section{References}

1. Image courtesy dr sinhasan mdzah (2008) The medical encyclopaedia. In: Heuper WC (Ed.) A cancer journal for clinicians 9(3).

\section{Your next submission with JuniperPublishers will reach you the below assets}

- Quality Editorial service

- Swift Peer Review

- Reprints availability

- E-prints Service

- Manuscript Podcast for convenient understanding

- Global attainment for your research

- Manuscript accessibility in different formats

( Pdf, E-pub, Full Text, audio)

- Unceasing customer service

Track the below URL for one-step submission https://juniperpublishers.com/online-submission.php 